\title{
ANALISIS KARYA LUKIS PADA BOTOL KACA BEKAS DENGAN MENERAPKAN ORNAMEN SUMATERA UTARA OLEH SISWA KELAS XI SMAS AL-WASHLIYAH PASAR SENEN MEDAN T.A 2018/2019 DITINJAU DARI PRINSIP-PRINSIP DESAIN
}

\author{
Purnama Sari Siregar $^{1^{*}}$, Onggal Sihite ${ }^{2 *}$, Fuad Erdansyah ${ }^{3 *}$ \\ Program Studi Pendidikan Seni Rupa Jurusan Seni Rupa Fakultas Bahasa dan Seni \\ Universitas Negeri Medan \\ Jl. Willem Iskandar Pasar V Medan Estate, Kec, Percut Sei Tuan, Kab. Deli Serdang, Kode Pos 20371 \\ Sumatera Utara. Indonesia \\ Email: purnamakellinci@gmail.com
}

\begin{abstract}
Abstrak
Penelitian ini bertujuan untuk memperkenalkan ornamen Sumatera Utara kepada siswa serta melatih kemampuan siswa dalam melukis ornamen dengan menerapkan prinsip-prinsip desain. Melukis ornamen adalah salah satu cara mengenal dan memelihara ornamen. Tahapan penelitian ini diawali dengan pembelajaran tentang ornamen Sumatera Utara dan prinsip-prinsip desain. Selanjutnya siswa diberi tugas untuk melukis ornamen Sumatera Utara. Artinya, siswa bebas mengekspresikan konsepnya lewat bentuk-bentuk ornamen tersebut. Metode penelitian yang dilakukan adalah deskriptif kualitatif yang menganalisis pengetahuan ornamen dan karya lukis ornamen siswa berdasarkan prinsip desain. Hasil penelitian menunjukkan adanya peningkatan pengetahuan tentang ornamen Sumatera Utara dan cukup baik dalam penerapan prinsip desain pada praktik melukis ornamen.
\end{abstract}

Kata Kunci: ornamen, lukis, prinsip, desain.

\begin{abstract}
This research purpose to introduce the North Sumatera ornaments to students and practice their skill in painting of ornaments with using the principles of design. Painting the ornaments is one way to recognize and maintain ornaments. The Step of research is begin with learning about North Sumatera ornaments and the principles of design. Then, students are given the task to paint the North Sumatera ornaments. That mean, students are free to express their concept with the shapes of that ornaments. The method of research conducted is qualitative descriptive which analyzing the ornaments knowledge and ornaments painting of students based on the principles of design. The result of this research show that there is creasing of the knowledge about North Sumatera Ornaments, and good enough in practice of painting ornament.
\end{abstract}

Keywords: ornament, painting, principle, design.

\section{PENDAHULUAN}

Indonesia adalah negara yang memiliki banyak keragaman budaya mulai dari Sabang sampai Meraoke. Keragaman budaya tersebut menggambarkan identitas daerah kebudayaan masingmasing yang diwariskan secara turun temurun. Iwan (2007 : 34) dalam bukunya yang berjudul Antropologi mengatakan "Sebagian dari budaya terwujud dalam seni". Salah satu contoh seni dalam budaya adalah ornamen daerah. Selain mengandung ide dan tingkah laku, kebudayaan juga mengandung aspek material salah satunya adalah ornamen. Aspek material ini harus dipelihara agar tetap dikenal oleh masyarakat dari generasi ke generasi.
Seperti yang dikemukakan oleh Oho dan Md Idris (1980:39) bahwa "Kita sebagai generasi penerusnya tidak cukup hanya menghargai saja nilai-nilai keindahan motif tradisional melainkan harus juga dapat memeliharanya". Untuk memelihara ornamen tradisional tersebut penulis memiliki inisiatif untuk memperkenalkan kembali ornamen yang sudah jarang diketahui masyarakat. Pengenalan ornamen ini dapat dilakukan melalui sosialisasi maupun internalisasi. Internalisasi adalah cara yang paling mudah untuk memperkenalkan identitas kebudayaan salah satunya melalui pendidikan seni.

Pengenalan ornamen ini akan dituangkan melalui lukis. Penulis memilih lukis karena melukis ornamen berbeda dengan menggambar ornamen yang pada 


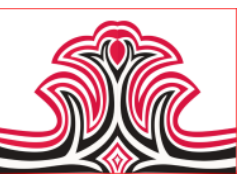

umumnya hanya memindahkan bentuk ornamen keatas suatu media, sedangkan dalam melukis ornamen terdapat ekspresi seniman dengan mengkombinasikan bentuk-bentuk ornamen yang ada serta telah terikat pada suatu konsep. Seni lukis adalah salah satu cabang dari seni rupa dua dimensi yang memiliki dua faktor estetik yakni ekstraestetik dan intraestetik. Faktor ekstraestetik mengandung nilai/makna yang terdapat dalam lukisan. Salah satu nilai pada faktor ekstraestetik adalah nilai kebudayaan. Pada faktor ekstraestetik, ornamen merupakan aspek material dari kebudayaan.

Pengenalan ornamen ini akan dituangkan melalui lukis. Penulis memilih lukis karena melukis ornamen berbeda dengan menggambar ornamen yang pada umumnya hanya memindahkan bentuk ornamen keatas suatu media, sedangkan dalam melukis ornamen terdapat ekspresi seniman dengan mengkombinasikan bentuk-bentuk ornamen yang ada serta telah terikat pada suatu konsep. Seni lukis adalah salah satu cabang dari seni rupa dua dimensi yang memiliki dua faktor estetik yakni ekstraestetik dan intraestetik. Faktor ekstraestetik mengandung nilai/makna yang terdapat dalam lukisan. Salah satu nilai pada faktor ekstraestetik adalah nilai kebudayaan. Pada faktor ekstraestetik, ornamen merupakan aspek material dari kebudayaan. Dengan demikian, ornamen berfungsi sebagai ekstraestetik yang digunakan sebagai subject matter dari karya lukis berbasis ornamen. Dengan kata lain, melukis berbasis ornamen berarti menjadikan ornamen sebagai ide dalam berkarya lukis yang akan dituangkan berdasarkan ekspresi pelukis melalui bentuk-bentuk ornamen yang ada tanpa menghilangkan identitas ornamen itu sendiri.

Selain faktor ekstraestetik, seni lukis juga dipengaruhi faktor intraestetik. Yang termasuk dalam faktor intraestetik salah satunya adalah media yang digunakan dalam melukis. Media yang digunakan dalam melukis berbasis ornamen ini adalah botol kaca bekas. Memanfaatkan botol kaca bekas berarti mengurangi penumpukan sampah khususnya botol kaca. Hal ini melatih kepekaan terhadap pemanfaatan barang bekas sebagai media dalam berkarya seni. Selain itu, melukis dengan botol merupakan suatu inovasi dalam praktik melukis.

Alasan teknis menggunakan media botol kaca bekas yaitu karena memiliki bahan dasar yang terbuat dari kaca. Menurut Anggun (2016:4), "Kaca adalah benda yang transparan, lumayan kuat, biasanya tidak bereaksi dengan bahan kimia, dan tidak aktif secara
Gorga Jurnal Seni Rupa

Volume 08 Nomor 01 Januari-Juni 2019

p-ISSN: 2301-5942 | e-ISSN: 2580-2380

biologis yang bisa dibentuk dengan permukaan yang sangat halus dan kedap air". Dengan kriteria-kriteria tersebut botol kaca merupakan benda yang tepat untuk dijadikan karya seni.

\section{KAJIAN TEORI}

\section{Analisis}

Karya seni adalah sarana kehidupan estetik. Dengan karya seni kemampuan dan pengalaman estetik menjadi bertambah kental dan menjadi milik sebagian dari nafas dan jiwa masyarakat (Dharsono, 2007:78). Sebagai sarana kehidupan estetis yang menjadi sebagian jiwa masyarakat, karya seni dapat dituangkan melalui tarian, musik maupun rupa. Dalam bidang rupa juga terdapat banyak cara dalam membuat karya seni salah satunya adalah melukis.

Spradley dalam Sugiyono (2014:334) menjelaskan "Analysis of any kind involve a way of thinking. It refers to the systematic examination of something to determine its parts, the relation among parts, and the relationship to the whole. Analysis is a search for patterns". Analisis dalam hal apapun adalah tentang cara berpikir. Hal ini berhubungan dengan pengujian yang sistematik terhadap sesuatu untuk menentukan bagian-bagian, hubungan antar bagian, dan hubungan secara keseluruhan.

Penelitian ini akan menganalisis hasil karya seni. Sehubungan dengan analisis terhadap seni diperlukan pengamatan berkelanjutan dan berulang secara terus menerus. Menurut Tjetjep (2011:241), "analisis data seni merupakan kajian data terhadap pernyataan umum mengenai hubungan di antara kategori data, analisis data seni menjadi dasar teori”.

In formal analysis, we endeavor to go"behind" the descriptive inventory to discover how the things we have named are constituted. But now we want to know how they have been organized as shape as areas of colours, as forms with particular contours, textures, and locations in space (Fildmand dalam I Wayan, 2007:223).

Analisis dalam penelitian ini adalah proses menelaah suatu hubungan antara bagian-bagian pada kategori data yang dilakukan dengan sistematis untuk mendapatkan data atau inforrmasi yang berhubungan dengan seni lukis. Dalam hal ini, analisis formal berusaha mengungkap bagaimana karya seni dapat terorganisasi sebagai bentuk bidang, warna, kontur, tekstur, ruang yang tersusun dalam prinsip-prinsip desain. Analisis tersebut mengarah pada analisis data intraestetik. 


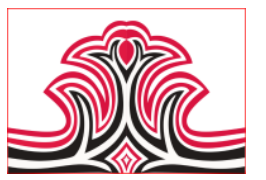

\section{Pemanfaatan Botol Kaca Bekas}

Dalam penelitian ini yang menjadi sorotan adalah sampah botol kaca bekas (termasuk dalam kategori sampah kaca). Sebagai masyarakat yang konsumtif tentunya kemasan botol kaca bekas sangat sering dijumpai disetiap rumah warga, restoran, warung, dan lain sebagainya. Untuk mengurangi sampah botol kaca bekas maka sebaiknya dilakukan pemanfaatan atau pengolahan kembali (daur ulang). Dalam pendidikan seni hal ini merupakan suatu masalah yang harus disorot. Dengan sentuhan kreativitas maka kemasan botol kaca bekas dapat berubah menjadi barang yang menarik. Selain dapat dijadikan koleksi benda seni pribadi, juga dapat menghasilkan nilai ekonomi.

\section{Pengertian dan Jenis Ornamen Sumatera Utara}

Ornamen sering juga disebut sebagai ragam hias. Ragam hias atau ornamen merupakan suatu gambar berbentuk pola-pola yang dibuat untuk memperindah suatu benda. Biasanya ornamen ini berasal dari bentuk-bentuk benda baik benda mati maupun benda hidup seperti tumbuhan, hewan, manusia, awan, matahari dan lain sebagainya.

Berikut adalah kelompok ornamen daerah Sumatera Utara berdasarkan etniknya yakni :

\section{1).Ornamen Toba}

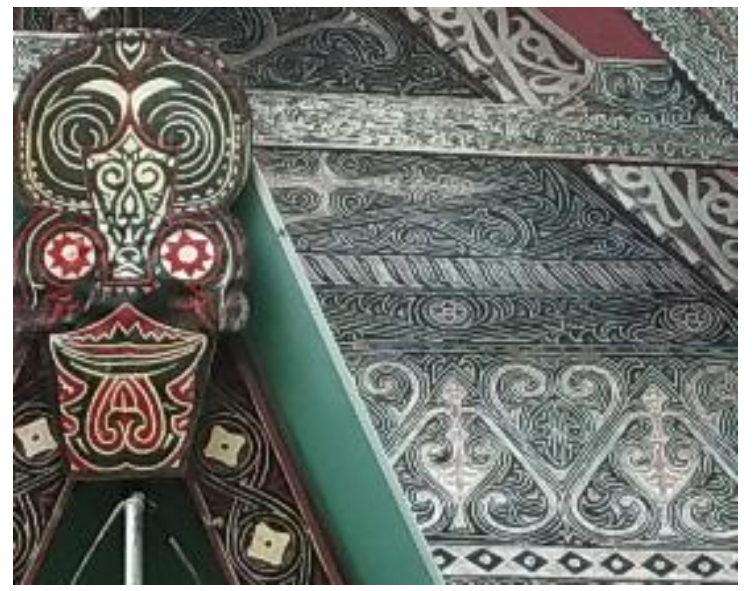

Gambar 1. Zoom Up Ornamen pada Paviliun Toba Samosir di PRSU Medan.

(Sumber: Purnama Sari Siregar, 2018)

Ornamen Toba terlihat hampir sama dengan ornamen daerah Sumatera Utara lainnya. Meskipun demikian terdapat perbedaan-perbedaan yang juga terlihat jelas jika diperhatikan. Ornamen Toba lebih banyak menggunakan kontur warna jika dibandingkan dengan ornamen daerah yang lain sehingga ornamen ini terlihat lebih padat. Kontur terluar berwarna hitam lalu putih, kemudian hitam lagi dan putih pada bagian tengahnya (sehingga terlihat pola hitam-putih-hitamputih-hitam-putih-hitam). Oleh karena itu ornamen
Gorga Jurnal Seni Rupa

Volume 08 Nomor 01 Januari-Juni 2019

p-ISSN: 2301-5942 | e-ISSN: 2580-2380

Toba terkesan lebih rumit jika dibandingkan dengan ornamen daerah lainnya.

\section{2).Ornamen Simalungun}

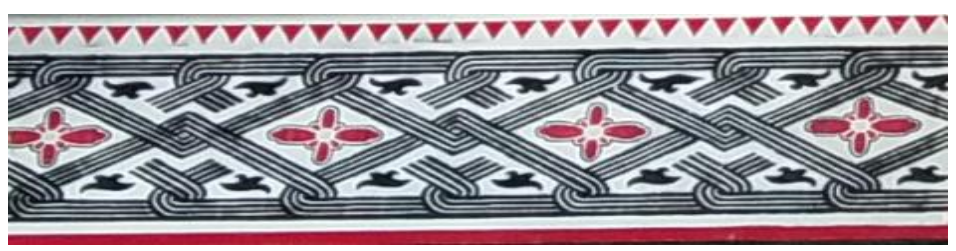

Gambar 2. Zoom Up Ornamen pada Paviliun Pemkab Simalungun di PRSU Medan.

(Sumber: Purnama Sari Siregar, 2018)

Pada ornamen Simalungun penerapan warna pada bentuk ornamen hanya menggunakan dua warna saja yaitu warna hitam sebagai kontur dan warna putih pada bagian tengah ornamen atau bisa juga kontur putih dan bagian dalam warna merah. Dengan kata lain ornamen Simalungun hanya menggunakan satu warna kontur dan satu warna untuk bentuk ornamen. Oleh karena itu ornamen Simalungun terlihat lebih sederhana jika dibandingkan dengan ornamen Toba. Warna merah yang digunakan pada ornamen ini berbeda dengan warna merah pada ornamen Toba.

\section{3).Ornamen Karo}

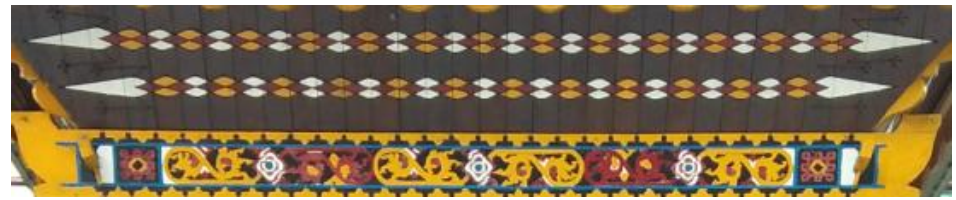

Gambar 3. Zoom Up Ornamen pada Paviliun Kab. Karo di PRSU Medan.

(Sumber: Purnama Sari Siregar, 2018)

Ornamen pada Karo memiliki kombinasi bentuk yang lebih beragam dan lebih rumit. Untuk kontur, ornamen ini hanya memiliki satu kontur warna, satu warna isian dan satu warna dasar atau background. Warna-warna yang digunakan biasanya adalah warna merah, hitam dan putih. Karena bentuknya yang rumit ornamen ini tidak perlu memiliki kontur yang berlapis-lapis (seperti pada ornamen Toba) untuk menciptakan kesan ramai.

\section{4).Ornamen Pakpak Dairi}

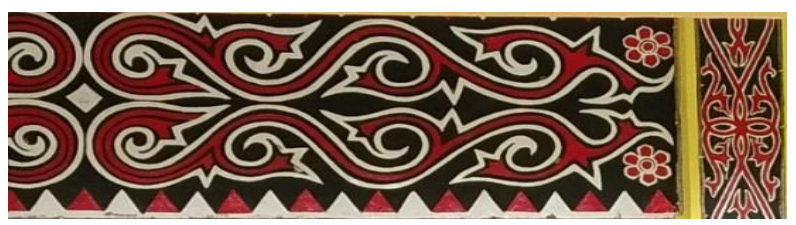


Gambar 4. Zoom Up Ornamen pada Paviliun Pakpak Dairi di PRSU Medan.

(Sumber: Purnama Sari Siregar, 2018)

Pada ornamen lain, kontur berada diluar bentuk ornamen namun tidak pada ornamen Pakpak Dairi. Ornamen Pakpak ini juga memiliki bentuk yang cukup rumit. Namun ornamen ini dikemas dengan meletakkan kontur pada bagian tengah bentuk ornamen seolah berfungsi sebagai garis tengah ornamen. Ini adalah salah satu ciri khas yang paling membedakan ornamen Pakpak Dairi dengan ornamen yang lain. Warna-warna yang digunakan pada ornamen ini adalah warna merah, hitam dan putih.

\section{5).Ornamen Angkola}

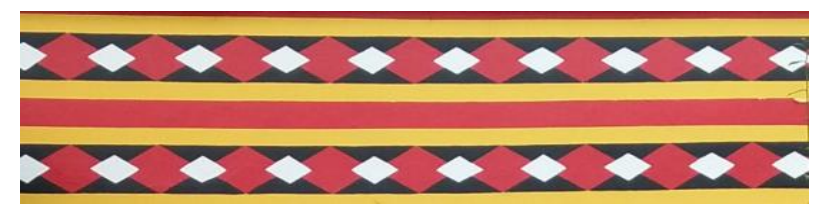

Gambar 5. Close Up Ornamen pada Paviliun Tapanuli Selatan di PRSU Medan.

(Sumber: Purnama Sari Siregar, 2018)

Ornamen Angkola memiliki ornamen-ornamen yang sangat sederhana jika dibandingkan dengan ornamen lainnya. Kebanyakan bentuknya hanya berupa perpaduan garis-garis lurus yang simentis hingga membentuk bidang-bidang kecil. Namun dengan kesederhanaan ini ornamen Angkola terlihat rapi. Pada ornamen ini hanya ada satu kontur warna, satu warna isian (bentuk ornamen) dan satu warna latar. Warna-warna yang digunakan adalah warna merah, hitam dan putih. namun terkadang ornamen Angkola juga menggunakan warna kuning pada beberapa ornamen.

\section{6).Ornamen Mandailing}

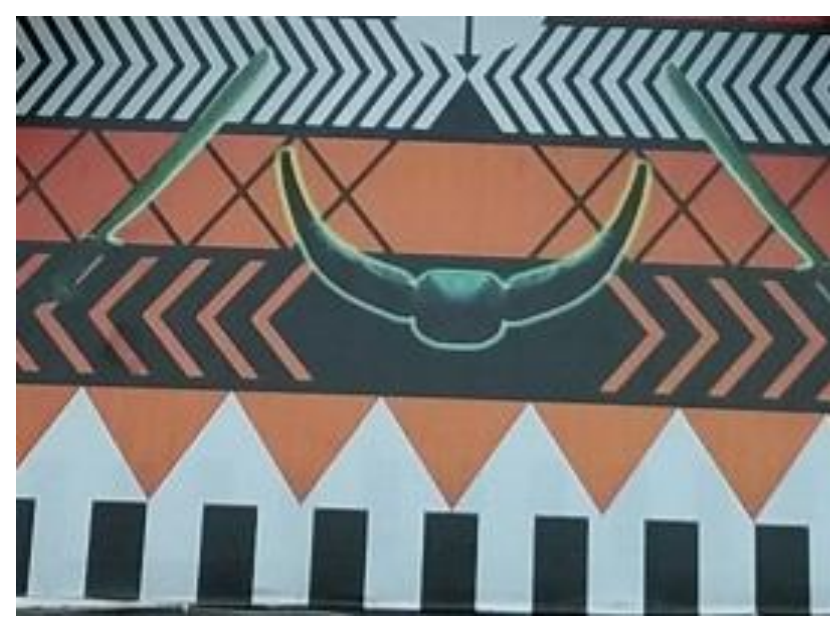

Gambar 6. Close Up Ornamen pada Paviliun Mandailing Natal
Gorga Jurnal Seni Rupa

Volume 08 Nomor 01 Januari-Juni 2019 p-ISSN: 2301-5942 | e-ISSN: 2580-2380

$$
\text { di PRSU Medan. }
$$

(Sumber: Purnama Sari Siregar, 2018)

Ornamen Mandailing memiliki kemiripan dengan ornamen Angkola. Bentuk ornamennya sangat sederhana yakni hanya berupa garis-garis lurus yang simentis hingga membentuk bidang-bidang kecil. Namun pada ornamen Mandailing, warna yang digunakan adalah warna hitam, putih dan merah saja. Jika dibandingkan dengan ornamen Nias, ornamen Mandailing terlihat lebih rapi dan terstruktur.

\section{7).Ornamen Melayu}

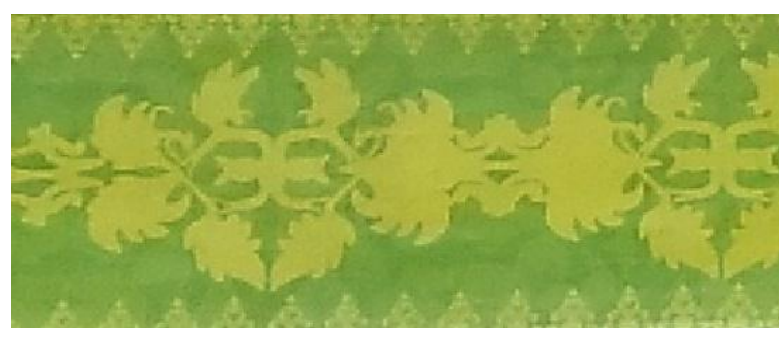

Gambar 7. Close Up Ornamen pada Paviliun Kab. Asahan di PRSU Medan.

(Sumber: Purnama Sari Siregar, 2018)

Ornamen melayu adalah ornamen yang memiliki warna yang khas dan sangat berbeda dengan ornamen Sumatera Utara lainnya. Warna yang biasa digunakan pada ornamen ini adalah warna hijau dan kuning. Bentuk-bentuk ornamen terinspirasi dari bentuk tumbuhan, alam serta bentuk geometris. Ornamen melayu banyak ditemukan pada bangunan mesjid.

\section{8).Ornamen Nias}

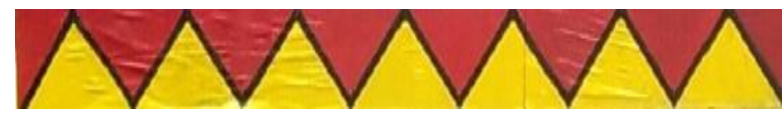

Gambar 8. Close Up Ornamen pada Paviliun Nias di PRSU Medan.

(Sumber: Purnama Sari Siregar, 2018)

Perbedaan ornamen Nias dengan ornamen Sumatera Utara lainnya cukup terlihat jelas. Jika pada ornamen daerah Toba, Karo, Dairi dan Mandailing didominasi oleh warna hitam, putih dan merah maka tidak jauh berbeda dengan ornamen Nias. Perbedaannya adalah ornamen Nias menggunakan banyak warna kuning. Ornamen ini juga memiliki bentuk yang sederhana dan memiliki kontur.

\section{Pengertian Lukisan}

Seni lukis adalah hasil curahan cita rasa subjek pencipta dengan menggunakan media karya yang berupa garis, bidang, warna, tekstur, volume dan 


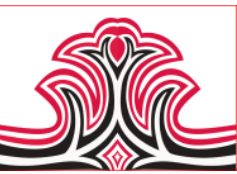

ruang dalam bidang dua dimensi. Gaya/corak lukisan antara lain natural, dekoratif, ekspresif, pointilis (titik-titik), linear (garis-garis), blocking (Sukimin dan Edy, 2008:7). Dalam penelitian ini, yang termasuk dalam faktor ekstraestetik adalah ornamen Sumatera Utara yang menjadi ide atau insprasi dalam berkarya lukis. Dan salah satu faktor intraestetik adalah media. Dalam hal ini peneliti menggunakan media botol kaca bekas dalam menuangkan karya lukis berbasis ornamen.

Dalam hal melukis kaca dengan media yang licin, maka kesabaran kita dimulai sejak awal menggoreskan pena atau rapio yang sangat menentukan kelenturan garis yang dibuat. Selanjutnya, kesabaran terus dituntut ketika memulai pengisian cat dengan gadasi warna, satu sama lain harus mempunyai jeda waktu untuk menghindari pencampuran warna yang tidak diinginkan. (Hetti, 2010:53).

\section{Prinsip-Prinsip Desain}

The tools of art consist of line, light and dark (value), light and shadow (chiaroscuro), color, texture, and form, their manipulation. Arrangement, and interrelation give us what we may call the Elements. These Elements solids and voids, geometric area, light and dark areas, and apace, all of which are dispose in accordance with design principles. The principles include domination, unity, balance, rhythm, and proportion. Their application toward a preconceived effect may be for intellectual or emotional purposes or both, and constitutes the design and quality of the work (Holt, 1962:249).

Adapun prinsip-prinsip desain yang akan dijadikan prinsip penilaian pada penelitian ini adalah sebagai berikut :
a. Kesatuan (Unity)
b. Keseimbangan (Balance)
c. Keselarasan (Harmony)
d. Pusat perhatian (Point of Interest)
e. Irama (Rythme)

Kelima prinsip diatas jika diterapkan dengan baik pada suatu karya seni khususnya pada karya lukis ornamen maka karya tersebut akan memiliki nilai estetis yang sangat baik. Oleh karena itu aspek-aspek tersebut diatas akan menjadi kriteria penilaian karya pada proposal ini.

\section{METODE PENELITIAN 1.Lokasi Penelitian}

Gorga Jurnal Seni Rupa

Volume 08 Nomor 01 Januari-Juni 2019

p-ISSN: 2301-5942 | e-ISSN: 2580-2380

Penelitian ini dilakukan di SMAS Al-Washliyah Pasar Senen Medan. Penelitian ini dilaksanakan pada semester Ganjil tahun ajaran 2018/2019.

\section{Populasi dan Sampel Penelitian}

Populasi dalam penelitian ini adalah seluruh siswa kelas XI SMAS Al-Washliyah Pasar Senen Medan yang berjumlah 33 orang. Pada penelitian ini, peneliti memilih siswa kelas XI SMAS Al-Washliyah Pasar Senen Medan sebagai sampel penelitian karena dianggap dapat memenuhi kriteria dalam pengumpulan informasi. Teknik sampling yang digunakan adalah total sampling. Sehingga jumlah sampel pada penelitian ini adalah 33 orang.

\section{Instrumen Penelitian}

Sesuai dengan objek penelitian dan metode yang digunakan maka instrumen yang dipakai pada penelitian ini adalah peneliti sendiri (human instrumen). Lexy (2017:168) juga mengatakan, "Kedudukan peneliti dalam penelitian kualitatif cukup rumit. Ia sekaligus merupakan perencana, pelaksana pengumpulan data, analisis, penafsir data dan pada akhirnya ia menjadi pelapor hasil penelitiannya. Borg and Gall pada Tjetjep (2011: 296) menyatakan bahwa, "Penelitian kualitatif lebih sulit bila dibandingkan dengan penelitian kuantitatif, karena data yang terkumpul bersifat subyektif dan instrumen sebagai alat pengumpul data adalah peneliti itu sendiri. Dalam hal ini, sebagai instrumen, peneliti harus mengamati setiap kegiatan yang dilakukan oleh siswa kelas XI SMAS Al-Washliyah Pasar Senen Medan dalam berkarya lukis berbasis ornamen dengan media botol kaca bekas.

\section{Teknik Pengumpulan Data}

Teknik pengumpulan data dilakukan dengan melakukan observasi langsung. Data tersebut kemudian akan dijadikan pedoman mendapatkan jawaban dari hasil penelitian. Teknik pengumpulan data merupakan prosedur yang sistematik dan standar untuk memperoleh data yang diperlukan menurut $\mathbf{M}$. Nazir (1998: 211). Dalam penelitian ini dilakukan pengamatan secara langsung terhadap hasil karya lukis siswa kelas XI SMAS Al-Washliyah Pasar Senen Medan dengan menerapkan ornamen Sumatera Utara yang ditinjau berdasarkan prinsip-prinsip desain.

\section{Teknik Analisis Data}

Analisis data yang digunakan yaitu analisis data kualitatif. Analisis data kualitatif adalah upaya yang dilakukan dengan jalan bekerja dengan data, mengorganisasikan data, memilah-milihnya menjadi satuan yang dapat dikelola, mensintesiskannya, 
mencari dan menemukan pola, menemukan apa yang penting dan apa yang dipelajari, dan memutuskan apa yang dapat diceritakan kepada orang lain (Bogdan dan Biklen dalam Lexy, 2017:248) “.

Data kualitatif dalam hal ini dilakukan terhadap data yang berupa informasi, uraian dalam bentuk bahasa prosa kemudian dikaitkan dengan data lainnya untuk mendapatkan kejelasan terhadap suatu kebenaran atau sebaliknya, sehingga memperoleh gambaran baru ataupun menguatkan suatu gambaran yang sudah ada dan sebaliknya (Joko, 2006:106).

\section{Aspek Penilaian}

\section{1).Aspek Penilaian Pengetahuan Ornamen}

Untuk mendapatkan data terkait pengetahuan siswa setelah diperkenalkannya ornamen, penulis akan membuat sejumlah pertanyaan tentang ornamen dalam bentuk gambar. Adapun format penilaiannya sebagai berikut:

$$
\text { Nilai }=\frac{\text { Jumlah Skor Perolehan }}{\text { Jumlah Skor Maksimal }} x 100=\cdots
$$

(Direktorat Jenderal Pendidikan Dasar dan Menengah Kementerian Pendidikan dan Kebudayaan, 2015).

Kriteria Penilaian :

A $=90-100$ (Sangat Baik)

$\mathrm{B}=80-89$ (Baik)

$\mathrm{C}=70-79$ (Cukup Baik)

$\mathrm{D}=<70$ (Kurang Baik)

Indikator Penilaian :

1. Amat Baik (A) apabila siswa mampu menjawab soal dengan benar minimal $80 \%$ dari jumlah soal.

2. Baik (B) apabila siswa mampu menjawab dengan benar minimal 70\% dari jumlah soal.

3. Cukup Baik (C) apabila siswa mampu menjawab dengan benar minimal $60 \%$ dari jumlah soal.

4. Kurang Baik (D) apabila siswa mampu menjawab dengan benar minimal $70 \%$ dari jumlah soal.

\section{2).Aspek Penilaian Penerapan Prinsip-Prinsip Desain}

Tabel 1. Aspek Penilaian Berdasarkan Prinsip Desain

\begin{tabular}{|l|c|c|c|c|c|c|c|}
\hline \multirow{2}{*}{ No } & \multirow{2}{*}{$\begin{array}{l}\text { Nama } \\
\text { Siswa }\end{array}$} & \multicolumn{5}{|c|}{ Aspek yang Dinilai } & \multirow{2}{*}{ Jumlah } \\
\cline { 3 - 7 } & & A & $B$ & $C$ & $D$ & E & \\
\hline 1. & & & & & & & \\
\hline 2. & & & & & & & \\
\hline
\end{tabular}

\begin{tabular}{|l|l|l|l|l|l|l|l|}
\hline 3. & & & & & & & \\
\hline$\ldots$ & & & & & & & \\
\hline 33 & & & & & & & \\
\hline
\end{tabular}

Keterangan tabel :

$\mathrm{A}=$ Unity (Kesatuan)

$\mathrm{B}=$ Balance (Keseimbangan)

$\mathrm{C}=$ Harmony $($ Keselarasan $)$

$\mathrm{D}=$ Point of Interest (Pusat Perhatian)

$\mathrm{E}=$ Rythme (Irama)

Keterangan Skor :

$4=$ Sangat Baik

$3=$ BaikB $=80-89$ (Baik)

$2=$ Cukup Baik $\quad \mathrm{C}=70-79$ (Cukup Baik)

$1=$ Kurang Baik

Kriteria Penilaian :

A $=90-100$ (Sangat Baik)

$\mathrm{D}=<70$ (Kurang Baik)

\section{3).Indikator Penilaian}

Tabel 2. Indikator Penilaian Aspek Kesatua (Unity)

\begin{tabular}{|l|l|l|l|}
\hline No & Keterangan & Skor & Deskriptor \\
\hline 1. & Sangat Baik & 4 & $\begin{array}{l}\text { Pertautan antar ornamen menunjang satu } \\
\text { sama lain dengan sangat baik }\end{array}$ \\
\hline 2. & Baik & 3 & $\begin{array}{l}\text { Pertautan antar ornamen menunjang satu } \\
\text { sama lain dengan baik }\end{array}$ \\
\hline 3. & Cukup Baik & 2 & $\begin{array}{l}\text { Pertautan antar ornamen menunjang satu } \\
\text { sama lain dengan cukup baik }\end{array}$ \\
\hline 4. & Kurang Baik & 1 & $\begin{array}{l}\text { Pertautan antar ornamen menunjang satu } \\
\text { sama lain dengan kurang baik }\end{array}$ \\
\hline
\end{tabular}

Tabel 3. Indikator Penilaian Aspek Keseimbangan (Balance)

\begin{tabular}{|l|l|c|l|}
\hline No & Keterangan & Skor & \multicolumn{1}{c|}{ Deskriptor } \\
\hline 1. & Sangat Baik & 4 & $\begin{array}{l}\text { Penataan bentuk dan ukuran ornamen } \\
\text { satu dengan yang lainnya menimbulkan } \\
\text { komposisi yang sangat baik }\end{array}$ \\
\hline 2. & Baik & 3 & $\begin{array}{l}\text { Penataan bentuk dan ukuran ornamen } \\
\text { satu dengan yang lainnya menimbulkan } \\
\text { komposisi yang baik }\end{array}$ \\
\hline 3. & Cukup Baik & 2 & $\begin{array}{l}\text { Penataan bentuk dan ukuran ornamen } \\
\text { satu dengan yang lainnya menimbulkan } \\
\text { komposisi yang cukup baik }\end{array}$ \\
\hline 4. & Kurang Baik & 1 & $\begin{array}{l}\text { Penataan bentuk dan ukuran ornamen } \\
\text { satu dengan yang lainnya menimbulkan } \\
\text { komposisi yang kurang baik }\end{array}$ \\
\hline
\end{tabular}


Tabel 4. Indikator Penilaian Aspek Keselarasan (Harmony)

\begin{tabular}{|l|l|c|l|}
\hline No & \multicolumn{1}{|c|}{ Keterangan } & Skor & \multicolumn{1}{c|}{ Deskriptor } \\
\hline 1. & Sangat Baik & 4 & $\begin{array}{l}\text { Penataan bentuk dan ukuran } \\
\text { ornamen satu dengan yang lainnya } \\
\text { menimbulkan komposisi yang sangat } \\
\text { baik }\end{array}$ \\
\hline 2. & Baik & 3 & $\begin{array}{l}\text { Penataan bentuk dan ukuran } \\
\text { ornamen satu dengan yang lainnya } \\
\text { menimbulkan komposisi yang baik }\end{array}$ \\
\hline 3. & Cukup Baik & 2 & $\begin{array}{l}\text { Penataan bentuk dan ukuran } \\
\text { ornamen satu dengan yang lainnya } \\
\text { menimbulkan komposisi yang cukup } \\
\text { baik }\end{array}$ \\
\hline 4. & Kurang Baik & 1 & $\begin{array}{l}\text { Penataan bentuk dan ukuran } \\
\text { ornamen satu dengan yang lainnya } \\
\text { menimbulkan komposisi yang } \\
\text { kurang baik. }\end{array}$ \\
\hline
\end{tabular}

Tabel 5. Indikator Penilaian Aspek Pusat Perhatian (Point of Interest)

\begin{tabular}{|l|l|c|l|}
\hline No & Keterangan & Skor & \multicolumn{1}{c|}{ Deskriptor } \\
\hline 1. & Sangat Baik & 4 & $\begin{array}{l}\text { Pemilihan dan penataan ornamen sebagai } \\
\text { pusat perhatian sangat baik }\end{array}$ \\
\hline 2. & Baik & 3 & $\begin{array}{l}\text { Pemilihan dan penataan ornamen sebagai } \\
\text { pusat perhatian baik }\end{array}$ \\
\hline 3. & Cukup Baik & 2 & $\begin{array}{l}\text { Pemilihan dan penataan ornamen sebagai } \\
\text { pusat perhatian cukup baik }\end{array}$ \\
\hline 4. & Kurang Baik & 1 & $\begin{array}{l}\text { Pemilihan dan penataan ornamen sebagai } \\
\text { pusat perhatian kurang baik }\end{array}$ \\
\hline
\end{tabular}

Tabel 6. Indikator Penilaian Aspek Irama (Rythme)

\begin{tabular}{|l|l|c|l|}
\hline No & Keterangan & Skor & \multicolumn{1}{|c|}{ Deskriptor } \\
\hline 1. & Sangat Baik & 4 & $\begin{array}{l}\text { Pengulangan bentuk ornamen disusun } \\
\text { dengan sangat baik }\end{array}$ \\
\hline 2. & Baik & 3 & $\begin{array}{l}\text { Pengulangan bentuk ornamen disusun } \\
\text { dengan baik }\end{array}$ \\
\hline 3. & Cukup Baik & 2 & $\begin{array}{l}\text { Pengulangan bentuk ornamen disusun } \\
\text { dengan cukup baik }\end{array}$ \\
\hline 4. & Kurang Baik & 1 & $\begin{array}{l}\text { Pengulangan bentuk ornamen disusun } \\
\text { dengan kurang baik }\end{array}$ \\
\hline
\end{tabular}

$$
\text { Nilai }=\frac{\text { Jumlah skor perolehan }}{\text { Jumlah skor maksimal }} \times 100=\cdots
$$

(Sumber : Direktorat Jenderal Pendidikan Dasar dan Menengah Kementerian Pendidikan dan Kebudayaan 2015).

HASIL DAN PEMBAHASAN

\section{Hasil}

\section{1). Hasil Penilaian Berdasarkan Pengetahuan \\ Ornamen.}

Gorga Jurnal Seni Rupa

Volume 08 Nomor 01 Januari-Juni 2019

p-ISSN: 2301-5942 | e-ISSN: 2580-2380

Untuk mengukur peningkatan pengetahuan siswa terhadap ornamen Sumatera Utara, peneliti melakukan pre-test dan post-test. Data hasil test yang diperoleh sebelum dan setelah dilaksanakan kegiatan melukis berbasis ornamen adalah sebagai berikut :

Tabel 7. Daftar Nilai Pre-Test dan Post-Test Siswa tentang Pengetahuan Ornamen

\begin{tabular}{|c|c|c|c|}
\hline No & Nama & Pre-Test & Post-Test \\
\hline 1 & Ahmad Sahdan & 43 & 75 \\
\hline 2 & Amanda Devina & 28,5 & 85 \\
\hline 3 & Amira Balqis & 14 & 85 \\
\hline 4 & Ayu Nur Ningsih & 14 & 80 \\
\hline 5 & Bimantara Surya & 43 & 85 \\
\hline 6 & Egi Satriawan & 14 & 65 \\
\hline 7 & Fadia Rivanka & 14 & 85 \\
\hline 8 & Fadil Arya Wiguna & 14 & 80 \\
\hline 9 & Fasha Arintifal & 43 & 85 \\
\hline 10 & Fikri Fadli & 57 & 85 \\
\hline 11 & Fira Aulia & 0 & 85 \\
\hline 12 & Gazasakila & 14 & 85 \\
\hline 13 & Gilang Falahi & 43 & 90 \\
\hline 14 & Kurniawan & 14 & 80 \\
\hline 15 & Lafifa Ramadhani & 14 & 75 \\
\hline 16 & Lia Anggaraini & 57 & 75 \\
\hline 17 & M. Dafi Farezi & 0 & 65 \\
\hline 18 & M. Agung P. & 0 & 65 \\
\hline 19 & M. Amar Falah & 28,5 & 75 \\
\hline 20 & M. Dafa Fareza & 28,5 & 75 \\
\hline 21 & M. Darwis & 57 & 85 \\
\hline 22 & M. Habib Husaini & 14 & 80 \\
\hline 23 & M. Ikhsan & 43 & 75 \\
\hline 2 & M. Ikrom Pulungan & 14 & 75 \\
\hline 25 & M. Ilham Syaputra & 57 & 80 \\
\hline 26 & Miftahul Jannah & 14 & 85 \\
\hline 27 & Nur Jannah & 28,5 & 80 \\
\hline 28 & Redi Novandri & 14 & 85 \\
\hline 29 & Riny Dewanti & 43 & 85 \\
\hline 30 & Rizky Ramadhani & 28,5 & 85 \\
\hline 31 & Said Aqil Nasution & 14 & 80 \\
\hline 32 & Tengku Ahmad & 43 & 80 \\
\hline 33 & Wahyu Irawan & 0 & 75 \\
\hline \multicolumn{2}{|r|}{ Rata-rata Nilai } & 26 & 80 \\
\hline
\end{tabular}

\section{2). Penilaian Berdasarkan Penerapan Prinsip-} Prinsip Desain.

Penilaian terhadap prinsip-prinsip desain ditinjau berdasarkan beberapa aspek yaitu unity (kesatuan), balance (keseimbangan), harmony (keselarasan), point of interest (pusat perhatian) dan rythme (irama). 
Tabel 8. Daftar Nilai Penerapan Prinsip-Prinsip Desain

\begin{tabular}{|c|c|c|c|c|c|c|c|c|}
\hline \multirow{2}{*}{ No } & \multirow{2}{*}{$\begin{array}{l}\text { Nama } \\
\text { Siswa }\end{array}$} & \multicolumn{5}{|c|}{ Aspek yang Dinilai } & \multirow{2}{*}{$\begin{array}{c}\text { Ju } \\
\mathbf{m} \\
\text { lah }\end{array}$} & \multirow{2}{*}{$\begin{array}{c}\text { Rata- } \\
\text { rata } \\
(\mathbf{R})\end{array}$} \\
\hline & & A & $B$ & $C$ & $D$ & $\mathrm{E}$ & & \\
\hline 1. & Ahmad Sahdan & 67 & 67 & 68 & 65 & 67 & 334 & 66,8 \\
\hline 2. & $\begin{array}{l}\text { Amanda } \\
\text { Devina }\end{array}$ & 75 & 65 & 75 & 76 & 65 & 356 & 71,2 \\
\hline 3. & Amira Balqis & 73 & 75 & 74 & 75 & 72 & 369 & 73,8 \\
\hline 4. & $\begin{array}{l}\text { Ayu Nur } \\
\text { Ningsih }\end{array}$ & 69 & 71 & 70 & 68 & 69 & 347 & 69,4 \\
\hline 5. & $\begin{array}{l}\text { Bimantara } \\
\text { Surya }\end{array}$ & 75 & 75 & 75 & 67 & 74 & 366 & 73,2 \\
\hline 6. & Egi Satriawan & 64 & 63 & 64 & 63 & 64 & 318 & 63,6 \\
\hline 7. & Fadia Rivanka & 70 & 71 & 70 & 75 & 70 & 356 & 71,2 \\
\hline 8. & $\begin{array}{l}\text { Fadil Arya } \\
\text { Wiguna }\end{array}$ & 88 & 88 & 87 & 90 & 86 & 439 & 87,8 \\
\hline 9. & Fasha Arintifal & 83 & 85 & 82 & 90 & 84 & 424 & 84,8 \\
\hline 10. & Fikri Fadli & 90 & 90 & 90 & 90 & 90 & 450 & 90 \\
\hline 11. & Fira Aulia & 86 & 86 & 86 & 87 & 85 & 430 & 86 \\
\hline 12. & Gaza Sakila & 83 & 84 & 83 & 85 & 82 & 417 & 83,4 \\
\hline 13. & Gilang Falahi & 85 & 87 & 85 & 90 & 85 & 432 & 86,4 \\
\hline 14. & Kurniawan & 80 & 80 & 80 & 82 & 80 & 402 & 80,4 \\
\hline 15. & $\begin{array}{l}\text { Lafifa } \\
\text { Ramadhani }\end{array}$ & 75 & 78 & 79 & 70 & 77 & 379 & 75,8 \\
\hline 16. & Lia Anggraini & 90 & 90 & 89 & 90 & 85 & 444 & 88,8 \\
\hline 17. & $\begin{array}{l}\text { M. Agung } \\
\text { Pulungan }\end{array}$ & 83 & 83 & 83 & 85 & 83 & 417 & 83,4 \\
\hline 18. & M. Amar Falah & 81 & 78 & 82 & 75 & 90 & 406 & 81,2 \\
\hline 19. & M. Dafi Farezi & 66 & 66 & 65 & 65 & 66 & 328 & 65,6 \\
\hline 20. & $\begin{array}{l}\text { M. Dafa } \\
\text { Fareza }\end{array}$ & 70 & 73 & 72 & 70 & 72 & 357 & 71,4 \\
\hline 21. & M. Darwis & 75 & 75 & 76 & 78 & 78 & 382 & 76,4 \\
\hline 22. & $\begin{array}{l}\text { M. Habib } \\
\text { Husaini S. }\end{array}$ & 84 & 84 & 85 & 70 & 83 & 406 & 81,2 \\
\hline 23. & M. Ikhsan & 60 & 60 & 60 & 60 & 60 & 300 & 60 \\
\hline 24. & $\begin{array}{l}\text { M. Ikrom } \\
\text { Pulungan }\end{array}$ & 75 & 73 & 78 & 78 & 73 & 377 & 75,4 \\
\hline 25. & $\begin{array}{l}\text { M. Ilham } \\
\text { Syaputra }\end{array}$ & 67 & 70 & 68 & 65 & 67 & 337 & 67,4 \\
\hline 26. & $\begin{array}{l}\text { Miftahul } \\
\text { Jannah }\end{array}$ & 84 & 84 & 84 & 85 & 85 & 422 & 84,4 \\
\hline 27. & Nur Jannah & 67 & 65 & 68 & 65 & 66 & 331 & 66,2 \\
\hline 28. & Redi Novandri & 90 & 80 & 90 & 90 & 85 & 435 & 87 \\
\hline 29. & Rini Dewanti & 89 & 90 & 89 & 90 & 90 & 448 & 89,6 \\
\hline 30. & $\begin{array}{l}\text { Rizky } \\
\text { Ramadhani }\end{array}$ & 85 & 83 & 85 & 84 & 85 & 422 & 84,4 \\
\hline 31. & $\begin{array}{l}\text { Said Aqil } \\
\text { Nasution }\end{array}$ & 90 & 85 & 90 & 90 & 88 & 443 & 88,6 \\
\hline 32. & $\begin{array}{l}\text { Tengku } \\
\text { Ahmad }\end{array}$ & 80 & 80 & 80 & 78 & 82 & 400 & 80 \\
\hline 33. & Wahyu Irawan & 65 & 65 & 65 & 70 & 64 & 329 & 65,8 \\
\hline \multicolumn{2}{|r|}{ Jumlah } & $\begin{array}{c}256 \\
4\end{array}$ & $\begin{array}{l}25 \\
49\end{array}$ & $\begin{array}{l}25 \\
77\end{array}$ & $\begin{array}{l}25 \\
61\end{array}$ & $\begin{array}{l}25 \\
52\end{array}$ & $\begin{array}{l}12 . \\
803\end{array}$ & 2.560 \\
\hline \multicolumn{2}{|c|}{ Rata-Rata (R) } & 78 & 77 & 78 & 78 & 77 & $\begin{array}{r}387 \\
, 97\end{array}$ & 78 \\
\hline
\end{tabular}

\section{KESIMPULAN DAN SARAN}

\section{Kesimpulan}

Data hasil perbandingan nilai pre-test dan post-test menunjukkan adanya peningkatan ilmu pengetahuan siswa terkait ornamen Sumatera Utara. Berdasarkan
Gorga Jurnal Seni Rupa

Volume 08 Nomor 01 Januari-Juni 2019

p-ISSN: 2301-5942 | e-ISSN: 2580-2380

hasil pre-test $88,5 \%$ siwa tidak mengetahui ornamen Sumatera Utara dengan baik. Sedangkan hasil posttest menunjukkan bahwa $0,1 \%$ siswa belum mengetahui ornamen, $24,2 \%$ siswa cukup mengetahui, 63,6 \% siswa mengetahui dengan baik, dan $0,03 \%$ siswa mengetahui dengan sangat baik. Penelitian ini telah mencapai tujuannya untuk memperkenalkan ornamen kepada siswa khususnya kelas XI SMA Al-Washliyah Pasar Senen Medan.

Berdasarkan data pada tabel 4.1, rata-rata nilai pada prinsip kesatuan (unity) $=78$ (cukup baik), keseimbangan (balance) $=77$ (cukup baik), keselarasan (harmony) $=78$ (cukup baik), pusat perhatian $($ point of interest $)=78$ dan irama $($ rythme $)=$ 77. Dengan demikian penerapan prinsip desain pada karya siswa secara umum dikategorikan cukup baik dengan nilai rata-rata keseluruhan prinsip sebesar 78 (cukup baik). Dengan demikian disimpulkan bahwa kemampuan siswa dalam melukis ornamen juga sudah cukup baik. Oleh karena itu siswa masih perlu berlatih dan lebih berani dalam mengeluarkan ekspresi pada karyanya.

\section{Saran}

Hasil penelitian menunjukkan adanya peningkatan pengetahuan siswa terhadap ornamen Sumatera Utara. Namun kemampuan siswa dalam menerapkan prinsipprinsip desain pada karya lukis berbasis ornamen masih dalam kategori cukup baik yakni dengan nilai rata-rata 78 . Dengan demikian sebaiknya siswa berlatih lebih intensif sehingga hasil karya lukis berbasis ornamen siswa menjadi lebih baik untuk kedepannya. Dengan terus berlatih siswa juga akan semakin mengenal ornamen yang telah mereka pelajari. Dengan demikian melukis ornamen adalah salah satu cara untuk tetap mengingat ornamen Sumatera Utara.

\section{DAFTAR RUJUKAN}

Anggun, Prameswari. (2006). Memanfaatkan Sampah Botol Kaca Sebagai Bandul Aksesoris. $e$ Proceeding of Art \& Design Universitas Telkom Bandung.. 03(02).-

Dharsono Sony Kartika. (2007). Kritik Seni. Bandung: Rekayasa Sains Bandung.

Direktorat Jenderal Pendidikan Dasar dan Menengah Kementerian Pendidikan dan Kebudayaan 2015.

Hetti, Restianti. (2010). Mengenal Jenis Kerajinan Nusantara. Bogor: Quadra.

Holt, Rinehart and Winston. (1958). Understanding

The Art. America: United States of America.

I Wayan, Suardana. (--------). Pengembangan Metode Analisis Bentuk Dalam Pengajaran Seni Lukis 
di Jurusan Pendidikan Seni Rupa. Jurnal UNY.05(02).-

Iwan, Fadila. (2007). Antropolog. Semarang: Bengawan Ilmu.

Joko, Subagyo. (2006). Metode Penelitian Dalam Teori dan Praktek. Jakarta: Rineka Cipta.

Lexy, Moleong. (2017). Metodologi Penelitian Kualitatif. Bandung: Rosdakarya

M. Nazir. (1998). Metode Penelitian. Jakarta: Ghalia Indonesia.

Oho, Garha dan Md, idris. (1980). Pendidikan Kesenian Seni Rupa Program Spesialisasi II. Jakarta: Gramedia.

Ornamen pada Paviliun di PRSU (Pekan Raya Sumatera Utara) Medan, 2018.

Sugiyono. (2014). Metode Penelitian Pendidikan. Bandung: Alfabeta.

Sukimin A.W dan Edy Sutandur. 2008. Terampil Berkarya Seni Rupa 1. Solo: Tiga Serangkai.

Tjetjep, Rohendi. (2011). Metodologi Penelitian Seni. Semarang: Prima Nusantara. 